\title{
WATER CIRCULATION AND ICE ACCRETION BENEATH WARD HUNT ICE SHELF (NORTHERN ELLESMERE ISLAND, CANADA), DEDUCED FROM SALINITY AND ISOTOPE ANALYSIS OF ICE CORES
}

by

\author{
Martin O. Jeffries and William M. Sackinger
}

(Geophysical Institute, University of Alaska, Fairbanks, AK 99775-0800, U.S.A.)

H. Roy Krouse

(Department of Physics, University of Calgary, Calgary, Alberta T2N 1N4, Canada)

and

Harold V. Serson

(977 Stellyscross Road, Brentwood Bay, British Columbia V0S 1A0, Canada)

\begin{abstract}
Ice-core drilling and ice-core analysis (electrical conductivity-salinity, ${ }^{18} \mathrm{O},{ }^{3} \mathrm{H}$, density) reveal that the internal structure of the west Ward Hunt Ice Shelf contrasts sharply with that of the east ice shelf. The west ice shelf contains a great thickness $(\geqslant 22 \mathrm{~m})$ of sea ice (mean salinity, $2.22 \%$; mean $\delta^{18} \mathrm{O},-0.8 \%$ ), whereas the east ice shelf is entirely of meteoric or fresh-water ice (mean salinity $<0.01 \%$; mean $8^{18} \mathrm{O},-29.7 \%$ ). High tritium activities are found only in ice from near the bottom of the east and west ice shelves. The contrasting ice-core data is considered to be a proxy record of variations in water circulation and bottom freezing beneath the ice shelf. The west shelf is underlain by sea water flowing into Disraeli Fiord. Sea ice accretes on to the bottom of the west ice shelf from the sea-water flowing into the fiord. Sea-water flowing out of the fiord is directed below the east ice shelf. However, the east ice shelf is not underlain directly by sea-water but by a layer of fresh water from the surface of Disraeli Fiord. In this region, ice growth resulting from the presence of this stable fresh-water layer has been accompanied by surface ablation over a period of perhaps the last 450 years. As a result, fresh-water ice has completely replaced any sea ice that originally grew in the region of the east ice shelf. Whereas the west and east shelves are underlain almost exclusively by sea-water and fresh water, ice in the south shelf is the result of freezing of fresh, brackish or sea water. This is attributed to mixing of the inflowing and outflowing waters.
\end{abstract}

\section{INTRODUCTION}

Arctic ice-shelf research has been concentrated on Ward Hunt Ice Shelf (Fig.1). It is now generally accepted that the ice shelf originally grew in situ as a thick, fast sea-ice sheet that thickened further by surface accumulation of snow and ice, and by bottom freezing of fresh, brackish or sea ice (Marshall 1955, Hattersley-Smith 1960, Ragle and others 1964, Lyons and others 1971).

The ice shelf is known to act as a floating dam that creates water stratification in Disraeli Fiord (Fig.1); here, a layer of fresh water, as deep as the draft of the ice shelf (about $44 \mathrm{~m}$ ), overlies deeper sea-water (Keys 1978, Jeffries and Krouse 1984). On occasion, frazil ice has been observed growing in the fiord at the halocline separating these two water bodies (Keys 1978). It has been suggested that bottom accretion is associated with similar water stratification and frazil-ice growth beneath the ice shelf (Lyons and others 1971, Keys 1978, Jeffries and Krouse 1984). Whereas Lyons and others (1971) and Keys (1978) favoured brackish ice growth associated with water stratification, Jeffries and Krouse (1984) found evidence only for fresh-water ice growth.

Largely because of the logistics problems involved, there have been no direct investigations of water circulation and freezing beneath the ice shelf. Instead, ice-core analysis, which has relied on cores from the south and west areas of the ice shelf only, has been used for indirect investigations (Ragle and others 1964, Lyons and others 1971). Since 1982, we have drilled and analyzed ice cores (Fig.1) from Ward Hunt Ice Shelf (including the first to be drilled in the east shelf) as part of a study of ice-shelf structure and growth. In this paper we present some results of this study, with particular reference to water circulation and freezing beneath the ice shelf.

GENERAL DESCRIPTION OF WARD HUNT ICE SHELF AND THE OCEANOGRAPHY OF DISRAELI FIORD

The ice shelf has a thickness of $45-50 \mathrm{~m}$ and an area of $440 . \mathrm{km}^{2}$. Ward Hunt Island is located at about the centre of the ice shelf, which is loosely divided into three areas: east, west, and south of the island. In 1982-83, a major ice-island calving from the east shelf occurred (Fig.1). Three deep ice cores drilled into one of these ice islands are the source of most of the data for the east shelf. The ice upper surface is characterized by a distinctive undulating topography of elongated ridges and troughs that are oriented parallel to the shore and to the prevailing coastal winds.

Although much of the ice exposed at the surface is non-saline, there are surface exposures of saline or basement ice (Fig.1) (Lyons and others 1971) that are generally considered to have accreted at the bottom (base) of the shelf. The exposure of basement ice can be attributed to surface-ice loss and lowering during the past 100-400 years (Crary 1960, Hattersley-Smith and Serson 1970).

As noted in the Introduction, the ice shelf causes fresh-water / sea-water stratification in Disraeli Fiord (Fig.1). The $\delta^{18} \mathrm{O}$ values of the fresh-water layer reflect its meteoric origin, i.e. water that was recently involved in atmospheric circulation, whereas the high tritium activities indicate recent fresh-water inflow (Jeffries and Krouse 1984). In spring, the fresh-water layer is $43-44 \mathrm{~m}$ deep (Keys 1978, Jeffries and Krouse 1984). Once, when the fresh-water layer was sampled at the end of summer, it was $60 \mathrm{~m}$ deep (Crary 1956). The available evidence is not conclusive, but it is likely that the fresh-water layer 


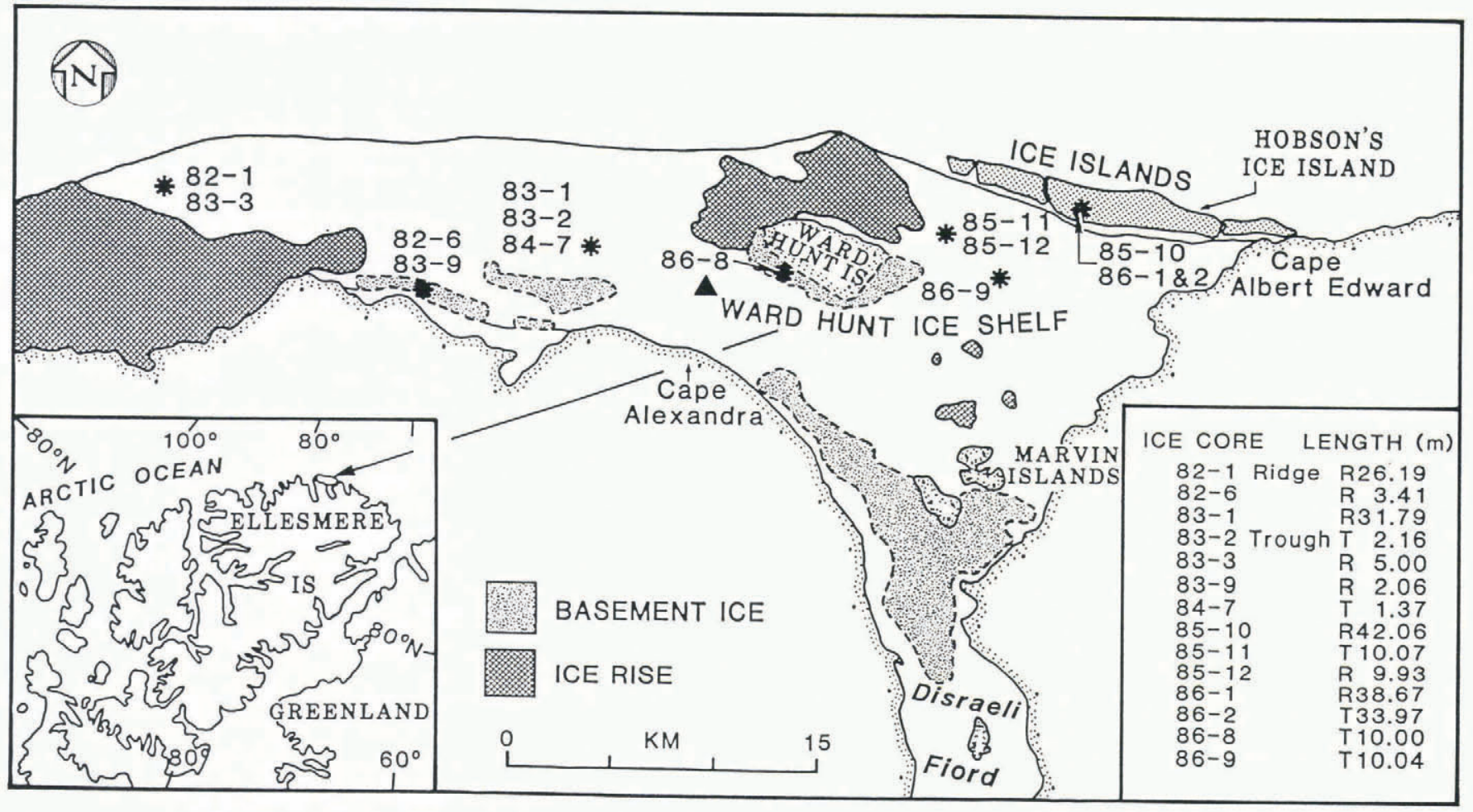

Fig.1. Location map of ice cores (asterisks) drilled in Ward Hunt Ice Shelf since 1982. The triangle south-west of Ward Hunt Island represents the general location of "brackish" ice cores (Lyons and others 1971). The former location of the ice islands has been reconstructed from airborne radar imagery.

deepens as melt water flows into the fiord in summer. During the winter it returns to a depth less than or equivalent to the draft of the ice-shelf dam.

Within the deeper sea-water in the fiord, it has been determined that the inflow is at the bottom and towards the south, whereas the outflow is close to the halocline and towards the north (Keys 1978). With regard to circulation and freezing beneath the ice shelf, the following questions remain: from which direction does sea-water flow into the fiord; in which direction does sea-water flow out of the fiord; if excess fresh water from the fiord surface flows out beneath the ice shelf, does it remain as a discrete layer or is it rapidly mixed with sea-water, and what type of ice growth is associated with this flow of water?

\section{METHODS}

Since 1982, we have drilled cores across the entire ice shelf, including three deep cores drilled in "Hobson's Ice Island", 2-3 years after calving (Fig.1). Core depths and ridge-trough locations are given in Figure 1. Ice density was measured by weighing in air on a triple-beam balance. Specific electrolytic conductivity (SEC) of the ice was measured by conductivity meter. SEC was the basis for the calculation of practical salinity according to the standard relation of UNESCO (1981). The oxygen-isotope abundances are expressed according to the $\delta^{18} \mathrm{O}$ scale, defined as

$$
\delta^{18} \mathrm{O}=\left\{\frac{\left({ }^{18} \mathrm{O} /{ }^{16} \mathrm{O}\right)_{\mathrm{S}}}{\left({ }^{18} \mathrm{O} /{ }^{16} \mathrm{O}\right)_{\text {SMOW }}}-1\right\} \times 10^{3}
$$

where $\left({ }^{18} \mathrm{O} /{ }^{16} / \mathrm{O}\right)$ is the ratio of the number of ${ }^{18} \mathrm{O}$ to ${ }^{16} \mathrm{O}$ atoms, $\phi_{0}$ is parts per thousand (per mil), subscript $s$ designates the unknown sample and Standard Mean Ocean Water (SMOW; Craig 1961) is the international reference standard.

Tritium analysis of water samples was undertaken by the Isotope Laboratory, Department of Earth Sciences, University of Waterloo, Ontario. Analysis was by direct liquid scintillation counting without prior enrichment.
Tritium activity of each sample was determined to an accuracy of $\pm 8 \mathrm{TU}$. After 1952, when the first thermonuclear device was tested in the atmosphere, atmospheric-tritium levels rose, and reached a maximum in 1963, when there was an increase of $2-3$ orders of magnitude over natural background levels. The latter fall within the range 0-25 TU (Gat 1980).

\section{RESULTS AND DISCUSSION}

On the basis of differences in the physical properties (salinity-SEC, ${ }^{18} \mathrm{O}$, and density) of ice in 14 ice cores, five different ice-types have been identified in Ward Hunt Ice Shelf. The five ice-types and data summaries for each are shown in Table I. The discussion of the results is limited to three particular cores $(83-1,85-10$, and 86-8) which show that each ice-type tends to be localized within a particular part of the ice shelf. The water circulation and ice accretion below the ice shelf is deduced from the ice-core results.

\section{Ice core 83-1, west Ward Hunt Ice Shelf}

This core was the deepest that was drilled in the western ice shelf, but it was not drilled right through to the bottom. Assuming an ice thickness of $45-50 \mathrm{~m}$ at the location of core $83-1$ (Fig.1), drilling ceased 13-18 m short of the bottom. Ice salinity and $\delta^{18} \mathrm{O}$ values show considerable variation and the core is divided into four distinct strata (Fig.2). Strata 1 and 3 have very low salinities and the $8^{18} \mathrm{O}$ values indicate a meteoric origin. In the case of stratum 1 , the ice has formed from accumulation of snow and ice at the ice-shelf surface; this type of ice is commonly referred to as iced firn (after Marshall 1955) and is the product of percolation and refreezing of melt water in the snow-pack. Iced firn is quite bubbly, hence the relatively low density compared to saline basement ice (Table I). In contrast to strata 1 and 3, a large part of core $83-1$ is saline basement ice (strata 2 and 4 ) and the $8^{18} \mathrm{O}$ values indicate a sea-water origin, i.e. strata 2 and 4 are sea ice. The brine in saline basement ice would account for the higher density values. 
TABLE I. DATA SUMMARY FOR ICE-TYPES FOUND IN ICE CORES FROM WARD HUNT ICE SHELF

\begin{tabular}{|c|c|c|c|c|}
\hline Iced firn & $\begin{array}{c}\text { Non-saline } \\
\text { basement ice } \\
\text { (east Ward Hunt } \\
\text { Ice Shelf) }\end{array}$ & $\begin{array}{c}\text { Non-saline } \\
\text { basement ice } \\
\text { (west Ward Hunt } \\
\text { Ice Shelf) }\end{array}$ & $\begin{array}{c}\text { Combination } \\
\text { basement ice } \\
\text { (south Ward Hunt } \\
\text { Ice Shelf) }\end{array}$ & $\begin{array}{c}\text { Saline } \\
\text { basement ice } \\
\text { (west Ward Hunt } \\
\text { Ice Shelf) }\end{array}$ \\
\hline
\end{tabular}

\begin{tabular}{|c|c|c|c|c|c|}
\hline Ice cores & $\begin{array}{c}82-1,83-1 \\
(\text { stratum } 1) \\
83-3\end{array}$ & $\begin{array}{c}85-10,85-11,85-12 \\
86-1,86-2,86-9\end{array}$ & 83-1 (stratum 3) & $86-8$ & $\begin{array}{c}82-6,83-1 \text { (strata } \\
2 \text { and } 4), 83-2 \\
83-9,84-7\end{array}$ \\
\hline $\begin{array}{l}\text { Mean SEC } \\
\left(\mu \mathrm{S} \mathrm{cm}^{-1}\right)\end{array}$ & $\begin{array}{c}20.32 \pm 42.5 \\
(203)\end{array}$ & $\begin{array}{c}5.86 \pm 2.8 \\
(507)\end{array}$ & $\begin{array}{l}274 \pm 184.0 \\
(5)\end{array}$ & $\begin{array}{c}1260 \pm 1140.0 \\
(39)\end{array}$ & $\begin{array}{c}3200 \pm 840.0 \\
(177)\end{array}$ \\
\hline $\begin{array}{l}\text { Mean salinity } \\
\left(\phi_{\infty}\right)\end{array}$ & $\begin{array}{l}<0.01 \\
(203)\end{array}$ & $\begin{array}{l}<0.01 \\
(507)\end{array}$ & $\begin{array}{c}0.18 \pm 0.11 \\
(5)\end{array}$ & $\begin{array}{c}0.70 \pm 0.7 \\
(39)\end{array}$ & $\begin{array}{l}2.22 \pm 0.6 \\
(177)\end{array}$ \\
\hline $\begin{array}{l}\text { Mean } \delta^{18} \mathrm{O} \\
(\%) \text { (\%) }\end{array}$ & $\begin{array}{c}-30.0 \pm 1.8 \\
(203)\end{array}$ & $\begin{array}{c}-29.7 \pm 1.7 \\
(221)\end{array}$ & $\begin{array}{c}-25.5 \pm 1.6 \\
(5)\end{array}$ & $\begin{array}{c}-14.2 \pm 8.2 \\
(22)\end{array}$ & $\begin{array}{l}-0.8 \pm 0.5 \\
\quad(182)\end{array}$ \\
\hline $\begin{array}{l}\text { Mean density } \\
\left(\mathrm{kg} \mathrm{m}^{-3}\right)\end{array}$ & $\begin{array}{l}875 \pm 31.0 \\
(94)\end{array}$ & $\begin{array}{c}875 \pm 17.5 \\
(374)\end{array}$ & $\begin{array}{c}\text { Not } \\
\text { measured }\end{array}$ & $\begin{array}{c}912 \pm 8.0 \\
(22)\end{array}$ & $\begin{array}{c}908 \pm 17.5 \\
(73)\end{array}$ \\
\hline
\end{tabular}

Notes: (1) Figures in brackets denote the number of sample measurements.

(2) For saline basement ice, the SEC-salinity data exclude the exceptionally high values in stratum 4B (core $83-1$ ) in order to avoid skewing the data. However, $\delta^{18} \mathrm{O}$ data include those from stratum $4 \mathrm{~B}$.

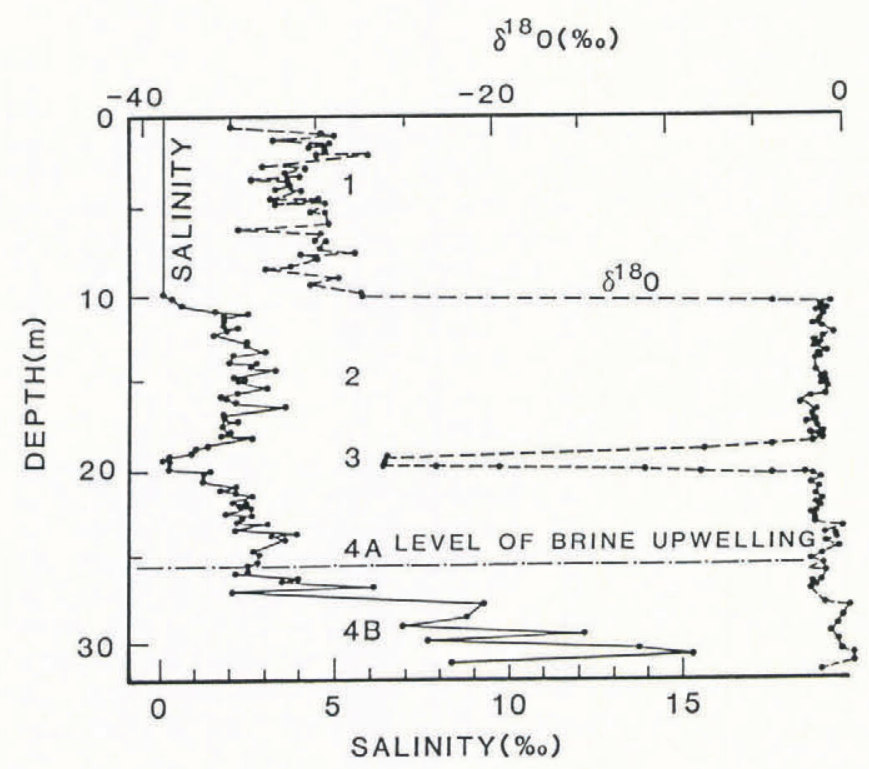

Fig.2. Salinity and $8^{18} \mathrm{O}$ profiles in ice core $83-1,9 \mathrm{~km}$ west of Ward Hunt Island. Sixty-eight hours after drilling ceased at $31.79 \mathrm{~m}$, brine had up-welled or infiltrated into the borehole to a level of $25.63 \mathrm{~m}$ below the ice surface. Ice-core salinity increases sharply just below this level; for this reason stratum 4 has been divided into $A$ and B.

Hattersley-Smith and others (1969) and $^{-}$Prager (unpublished) all had difficulty obtaining good returns during airborne radio echo-sounding of the western ice shelf. In each case it was suggested that the problem arose due to the presence of saline ice, although few ground-truth data were available. Our data confirm the presence of saline ice which, because of low permittivity, undoubtedly gives rise to large dielectric attenuation. Prager (unpublished) obtained faint internal reflections at depths of $15-25 \mathrm{~m}$ which were attributed to the transition from freshwater ice to saline ice. Although it is at $10 \mathrm{~m}$ depth, the transition from stratum 1 (iced firn) to stratum 2 (saline basement ice) is very abrupt and likely to give rise to an internal reflection.
An interesting phenomenon associated with the drilling of core 83-1 was brine up-welling in the bore hole (Fig.2). The level to which brine up-welled might represent the maximum hydraulic head and is probably the cause of the high ice salinities in stratum 4B (Fig.2). Although ice salinities increase in stratum $4 \mathrm{~B}$, there is no change in the ${ }^{18} \mathrm{O}$ values, which remain close to SMOW. However, the increase in salinity is associated with an increase in tritium values. Figure 3 shows that from the surface to $28 \mathrm{~m}$, tritium activities fall within natural background levels. Below $28 \mathrm{~m}$, higher tritium values occur and indicate a source of thermonuclear tritium.

Although core 83-1 was not drilled to the bottom of the ice shelf, the high tritium values in saline ice, with $\delta^{18} \mathrm{O}$ values that remain close to SMOW, indicate recent ice accretion from sea-water below the western ice shelf. Seismic sounding (Crary 1956) and hydrographic surveys (Crary 1956, personal communication from R. McDougall) indicate that a deep $(900 \mathrm{~m})$ trench, oriented west-east, lies below the western ice shelf. It is probable that the trench channels sea-water into Disraeli Fiord. The great thickness $(>12 \mathrm{~m})$ of stratum 4 alone suggests that the flow of seawater and the associated ice accretion has occurred over a long period below west Ward Hunt Ice Shelf. However, the non-saline basement ice (Table I) of stratum 3 (Fig.2) suggests that the western ice shelf was underlain by fresh water at least once in the past. This will be discussed further with reference to the eastern ice shelf.

\section{Ice core 85-10, east Ward Hunt Ice Shelf}

This ice core was drilled right through to the water below the ice. Salinity and $\delta^{18} \mathrm{O}$ profiles (Fig.4) show none of the stratigraphic variation evident in core 83-1 (Fig.2). Ice core $85-10$ has a very low salinity and the $8^{18} \mathrm{O}$ values indicate fresh-water ice of meteoric origin. This ice core is composed entirely of non-saline basement ice (Table I).

The absence of saline ice in the eastern shelf would account for the greater success of radio echo-sounding in this area. Hattersley-Smith and others (1969) obtained thicknesses of $30-40 \mathrm{~m}$, whereas Prager (unpublished) obtained $45-50 \mathrm{~m}$. The thickness of "Hobson's Ice Island" (Fig.1) varies between 41 and $43.5 \mathrm{~m}$ (personal communication from $R$. Verrall), confirming the greater reliability of radio echo-sounding of the eastern shelf.

As in core 83-1, much of the ice from "Hobson's Ice Island" has low, background levels of tritium (Fig.3). In 

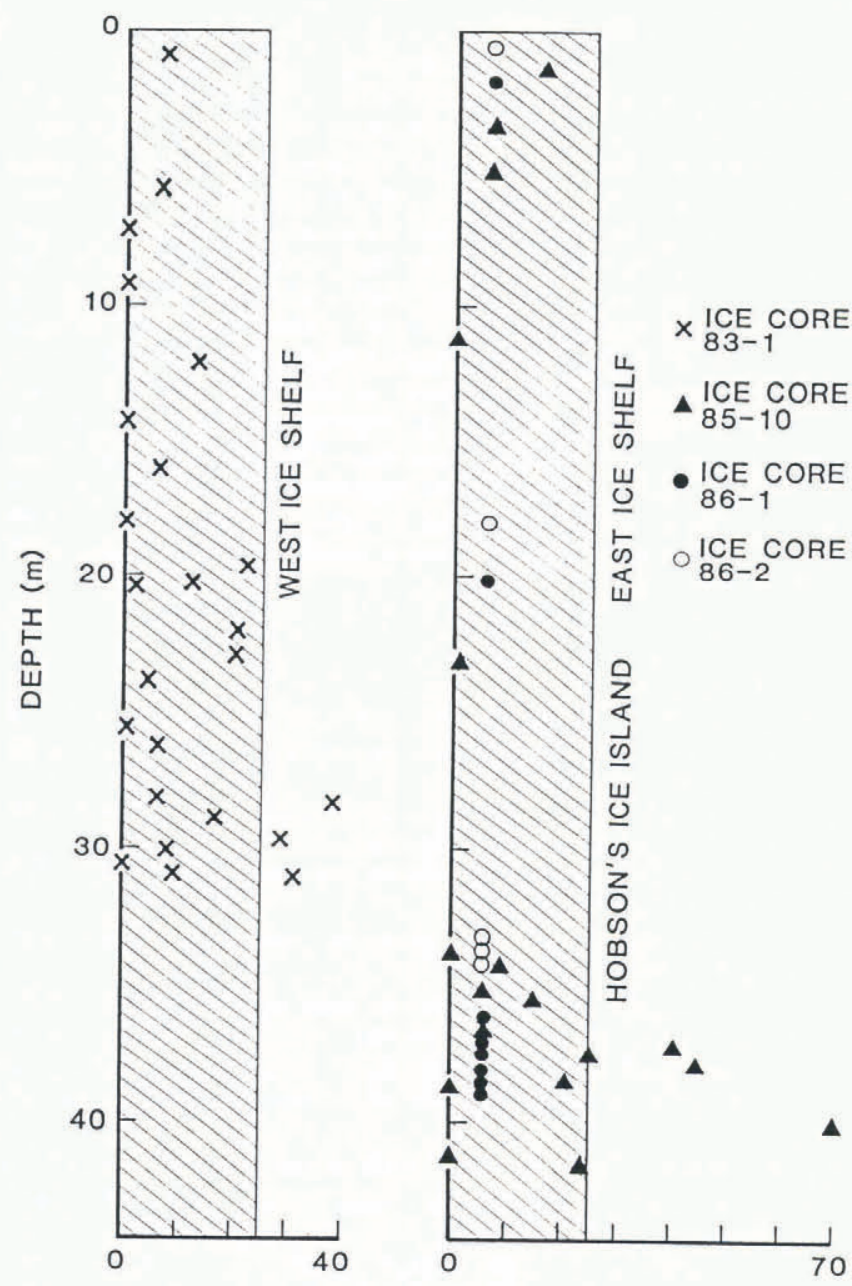

TRITIUM (TU)

Fig.3. Tritium activity in four deep ice cores from Ward Hunt Ice Shelf. The shaded areas represent natural background levels.

core 85-10, however, tritium values in the lowermost $5 \mathrm{~m}$ of ice are as much as twice those in core $83-1$. It is possible that the highest value $(71 \mathrm{TU}$ at $40 \mathrm{~m})$ is related to the 1963 atmospheric-tritium maximum. The high tritium values in ${ }^{18} \mathrm{O}$-depleted ice at the bottom of core $85-10$ must be the result of recent bottom-ice accretion from fresh or meteoric water.

The source of the fresh water below the eastern ice shelf is probably Disraeli Fiord. Hamblin and Carmack (1978) showed that in the Northern Hemisphere the Coriolis force causes water flowing into lakes to be deflected to the right. By analogy, we expect the tidally driven sea-water outflow from Disraeli Fiord to be deflected to the right, beneath the eastern ice shelf. It has been suggested before that fresh water from Disraeli Fiord also flows out beneath the ice shelf, albeit as a brackish water layer from which brackish ice grows (Lyons and others 1971, Keys 1978). Our ice-core evidence suggests that the fresh water does not mix with sea-water to form brackish water. Instead, it appears that fresh-water/sea-water stratification with associated $\mathrm{fresh} /$ meteoric ice accretion is extensive beneath the eastern shelf.

The chronology of tritium inputs to the atmosphere is well established, as is subsequent fallout in precipitation. The presence of tritium at the bottom of core 85-10 means that the ice has accreted quite recently, and that the data can also be used to determine the accretion rate. The thickness of the tritiated ice layer suggests a mean annual accretion rate of $95 \mathrm{~mm} \mathrm{a}^{-1}$ since 1963. This may be compared to the mean annual surface-ice loss of about $100 \mathrm{~mm} \mathrm{a}^{-1}$ since the early 1960s (Hattersley-Smith and Serson 1970, Serson 1979). Therefore, if climatic conditions are invariant, a situation would exist in which surface-ice loss is nearly balanced by bottom accretion, resulting in a

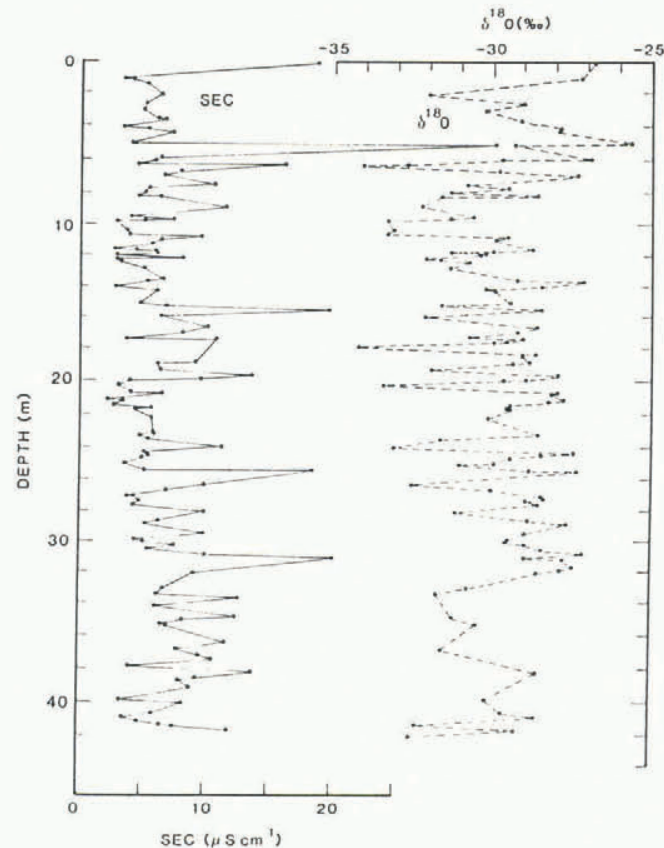

Fig.4. Specific electrolytic conductivity (SEC) and $\delta^{18} \mathrm{O}$ profiles in ice core $85-10$, "Hobson's Ice Island"/east Ward Hunt Ice Shelf.

complete replacement of ice from below. This process of vertical-upward ice movement would account for the eastern ice shelf being composed entirely of non-saline basement ice. If a maximum ice thickness of $45 \mathrm{~m}$ is assumed, this process would require about 450 years of overall negative mass balance. Evidence for this long period of negative mass balance has been found in the form of sponges and plant material in the basement ice around Ward Hunt Island (Fig.1). Crary (1960) obtained ${ }^{14} \mathrm{C}$ ages of $400-500$ years for the organic material and suggested that this was the time required for it to reach the surface after being frozen in at the bottom.

The outflow of fresh water from Disraeli Fiord has been traced by ice-core drilling and analysis of the eastern ice shelf. However, the non-saline basement ice of stratum 3 (Table I; Fig.2) suggests that water stratification and associated fresh-water ice growth once occurred below the western ice shelf. Jeffries and Krouse (1984) suggested that this could have occurred during an exceptionally warm climatic period when the volume of fresh water flowing into and out of Disraeli Fiord was far greater than it is today. Alternatively, there could have been a pulse of water from the land to the west of Cape Alexandra (Fig.1).

\section{Core 86-8, south Ward Hunt Ice Shelf}

Brackish ice was found to interfinger with sea ice in two deep cores drilled south-west of Ward Hunt Island (Fig.1) (Lyons and others 1971). Core 86-8 was drilled in the same area and although it is only a $10 \mathrm{~m}$ core, the salinity and $\delta^{18} \mathrm{O}$ data set is much larger than that of Lyons and co-workers. Salinity and $\delta^{18} \mathrm{O}$ are plotted on an $x-y$ graph (Fig.5).

Salinity and $\delta^{18} \mathrm{O}$ are linearly related (Fig.5) and the $\delta^{18} \mathrm{O}$ data show that the core contains fresh-water/meteoric ice in addition to brackish ice and sea ice. The brackish ice salinity and $\delta^{18} \mathrm{O}$ values of Lyons and others (1971) are also plotted for the purposes of comparison. Since ice core $86-8$ contains a combination of fresh, brackish, and sea ice it is termed "combination basement ice" (Table I).

Combination basement ice appears to be restricted to an area south of Ward Hunt Island, a location that lies between the western ice shelf with inflowing sea-water and the eastern ice shelf with outflowing sea-water and fresh water. The salinity and $\delta^{18} \mathrm{O}$ values of the ice are evidence of accretion from fresh, brackish, or sea-water. The greater and more frequent variability of ice properties suggests that water stratification in this area is less common 


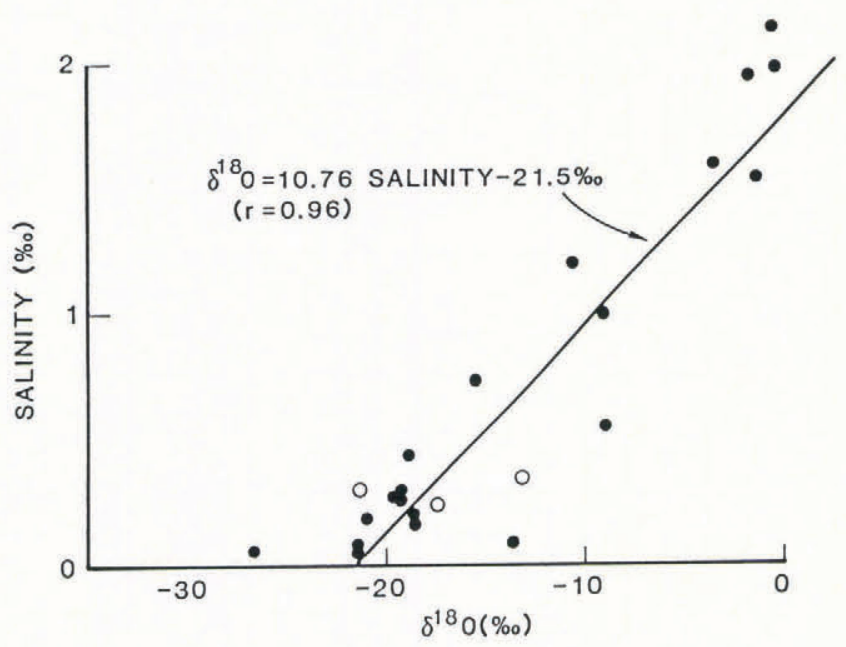

Fig.5. Salinity versus $\delta^{18} \mathrm{O}$ scattergram for ice core $86-8$ (dots), south Ward Hunt Ice Shelf. The regression line represents the relationship between salinity and $\delta^{18} \mathrm{O}$ in core 86-8 only. Open circles represent data for brackish basement ice (Lyons and others 1971).

than below the eastern ice shelf. The variability of water properties below the ice must be related to variations in the degree of fresh-water / sea-water mixing that may be due to the influence of local sea-floor topography or under-ice topography.

\section{CONCLUSION}

On the basis of ice-core drilling and analysis we have attempted to determine water circulation and freezing below Ward Hunt Ice Shelf, and their relationship to the inflow and outflow of water to/from Disraeli Fiord. Our interpretation is summarized in Figure 6. Sea-water flows into Disraeli Fiord beneath the west shelf and, apart from one known interruption, the ice has grown directly from sea-water. Sea-water flow out of the fiord occurs beneath the east shelf, but includes a discrete layer of fresh water directly below the ice shelf. Ice growth (probably frazil) from this fresh water, in balance with surface melting, has led to the complete removal of any sea ice that once grew east of Ward Hunt Island. South of Ward Hunt Island, due to local geometry that remains to be delineated, considerable water mixing occurs. Water strata there are subject to greater and more frequent mixing, which is reflected in the growth of fresh, brackish, or sea ice. The ice cores contain a proxy record of variations in water circulation beneath the Ward Hunt Ice Shelf. Now there is a need for an extended time series of direct measurements through the deployment of current meters, tide gauges, and CTDs below the ice shelf.

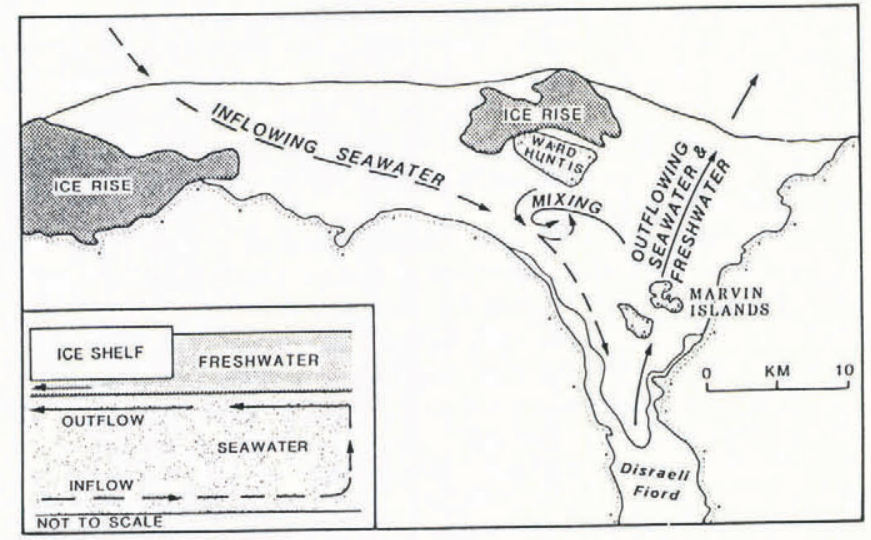

Fig.6. General water circulation below Ward Hunt Ice Shelf, deduced from salinity and isotope analysis of ice cores. A schematic representation of water stratification in Disraeli Fiord is also shown (inset).

\section{ACKNOWLEDGEMENTS}

Martin O Jeffries acknowledges the support of the following: Department of Geography, University of Calgary, PCSP (Director, G D Hobson), Defence Research Establishment Pacific, the Arctic Institute of North America, Gulf Canada, Dome Petroleum and Petro-Canada. H Roy Krouse acknowledges NSERC Canada funding of the stable-isotope laboratory at the University of Calgary. The ice-island project at the Geophysical Institute, University of Alaska, is funded by the U.S. Department of Energy (Morgantown Energy Technology Center). Our thanks to $\mathrm{Dr}$ $G$ Holdsworth for his help with drilling ice core 83-1 and to the P.U.N.S. Expedition (1985-86) to Ward Hunt Ice Shelf (leader, Sir Ranulph Fiennes) for drilling four $10 \mathrm{~m}$ ice cores. We also thank the Resolute Bay weather station (AES Canada) for allowing us to store the ice cores in one of their freezers. Dr W F Weeks kindly read the manuscript before submission.

\section{REFERENCES}

Craig H 1961 Standard for reporting concentrations of deuterium and oxygen-18 in natural waters. Science 133(3467): 1833-1834

Crary A P 1956 Geophysical studies along northern Ellesmere Island. Arctic 9(3): 155-165

Crary A P 1958 Arctic ice island and ice shelf studies. Part I. Arctic 11(1): 2-42

Crary A P 1960 Arctic ice island and ice shelf studies. Part II. Arctic 13(1): $32-50$

Gat J R 1980 The isotopes of hydrogen and oxygen in precipitation. In Fritz P, Fontes J C (eds) Handbook of environmental isotope geochemistry, Vol 1, The terrestrial environment. Amsterdam, Elsevier Scientific Publishing Co: $21-47$

Hamblin P F, Carmack E C 1978 River-induced current in a fjord lake. Journal of Geophysical Research 83(2): 885-899

Hattersley-Smith G 1960 Some remarks on glaciers and climate in northern Ellesmere Island. Geografiska Annaler 42(1): $45-48$

Hattersley-Smith G, Serson H V 1970 Mass balance of the Ward Hunt ice rise and Ice Shelf: a 10 year record. Journal of Glaciology 9(56): 247-252

Hattersley-Smith G, Fuzesy A, Evans S 1969 Operation Tanquary. Glacier depths in northern Ellesmere Island: airborne radio echo sounding in 1966. Ottawa Defence Research Board. Department of National Defence (DREO Technical note 69-6)

Jeffries M O, Krouse H R 1984 Arctic ice shelf growth, fiord oceanography and climate. Zeitschrift für Gletscherkunde und Glazialgeologie 20: 147-153

Keys J E 1978 Water regime of Disraeli Fiord, Ellesmere Island. Ottawa, Defence Research Establishment (Report 792)

Lyons J B, Savin S M, Tamburi, A F 1971 Basement ice, Ward Hunt Ice Shelf, Ellesmere Island, Canada. Journal of Glaciology 10(58): 93-100

Marshall E W 1955 Structural and stratigraphic studies of the northern Ellesmere Ice Shelf. Arctic 8(2): 109-114

Prager B T Unpublished Digital signal processing of UHF radio-echo sounding data from northern Ellesmere Island. (MSc thesis, University of British Columbia, 1983)

Ragle R H, Blair R G, Persson L E 1964 Ice core studies of Ward Hunt Ice Shelf, 1960. Journal of Glaciology 5(37): $39-59$

Serson H V 1979 Mass balance of the Ward Hunt ice rise and Ice Shelf: an eighteen year record. Victoria, BC, Defence Research Establishment Pacific. Research and Development Branch (Technical Memorandum 79-4)

UNESCO 1981 International oceanographic tables. Vol 3. UNESCO Technical Papers in Marine Science 39 